\title{
The role of the railway network of border areas in interstate cooperation
}

\author{
Natalia Popova ${ }^{1, *}$, and Elena Korkhovaya ${ }^{1}$ \\ ${ }^{1}$ Siberian Transport University, Dusi Kovalchuk st., 191, 630049, Novosibirsk, Russia
}

\begin{abstract}
The border areas of countries are aimed at playing a special role in the development of general economic and social relations, enhancing the geopolitical significance of regional interstate relations. The purpose of the work is to study and show the modern economic complex of border regions on the example of Russia and Mongolia, in which railway transport plays a significant role. Statistical and analytical comparison as a method of scientific analysis allowed examining in detail the territorial production complex of a large region, its resource dependence, and the conditionality of the functioning by the configuration of transport routes and transport accessibility indicators, both in Russia and Mongolia. The Russian railways, which connect Siberia and the Far East with the European regions of the country, continue to provide interdistrict and interregional economic relations at the present time. The Mongolian railways, which have a smaller length, perform a linking role between the fields of raw materials and the points of its processing or further transportation. The study showed that railways continue to be the basis for interregional cross-border connections. However, as the shortest transport route between the countries of Western, Central, Eastern Europe, and the countries of Central, East, and South-East Asia, the railways of the region in question, uniting the border regions of Mongolia and Russia, can strengthen their role in interstate cooperation and become the most important part of the international Eurasian transport corridors - the Steppe Route and the Silk Road.
\end{abstract}

\section{Introduction}

For many regions and countries of the world, railways were both a factor and a condition for economic development. For Russia, taking into account the country's considerable length along the East-West line and its location in the North-East of Eurasia, the railways of Siberia from the moment of the beginning of construction and mass exploitation (1891-1916) and to this day remain the most reliable type of communication routes, transportation on which are distinguished by their universality, both in space-time and in territorial-industry relation [1-2].

Geographically, the Siberian region covers an extensive part of the territory of Russia, about 9.8 million square kilometers. Structurally, Siberia is divided into Western Siberia,

*Corresponding author: pnb1512@yandex.ru 
Eastern Siberia, Transbaikal, and the Far East. Administratively - there are 4 republics, 6 territories ("krai"), 7 regions, 12 of which are part of the Siberian Federal District (SFD).

The border areas in the SFD are the republics - Altai, Buryatia, Tyva; territories ("krai") - Altai and Transbaikal; and the regions - Omsk and Novosibirsk.

The administrative formations of the republics of Altai, Tyva, Buryatia, and the Transbaikal Territory are directly adjacent to the Russian-Mongolian border, the land part of which is about 2.9 thousand $\mathrm{km}$. On the part of Mongolian, the northern territories of 8 aimaks - Bayan-Ulgiy, Uvs, Zavkhan, Khovsgel, Bulgan, Selenge, Hantiye, and Dornod are border areas [3].

Following Russian border regions have the railway transport infrastructure - the Republic of Buryatia and the Transbaikal region, and the Mongolian ones - the aimaks Selenge and Dornod, where the railway border crossing points (RCBP) or stations are located with customs inspection, handing over of freight cars and containers, maintenance. These Russian-Mongolian points Naushki - Sukhe - Bator and Solovyevsk - Erentsav are currently the main hubs of the logistics and transport interaction, which contributes to the economic development of the two countries [4].

\section{Main part and results of the study}

The geopolitical realities of modern times show that for the development of mutually beneficial cooperation between border countries, the most diverse aspects of their naturalresource and socio-economic potential can become productive. It is these features that determine the opportunities for business activity and the development of entrepreneurship first in their country, and then in cross-country contacts, in which transport routes play a significant role [5-8].

For the republics of Altai and Tyva, whose natural and resource potential is characterized by a diversity of mineral resources, water, forest, and energy resources, and the economy combines the development of traditional directions, for example, horse herding, velvet antler industry, and reindeer herding in agriculture, various mining, and woodworking, primary processing industries in the industry, the availability of transport routes is a condition for their own socio-economic development and a factor in the future ensuring the relevance of these entities in interregional and interstate cooperation [9].

At the present time, motor transport plays an important role in the life of the republics. The federal highway "Chuysk tract" (R-256, AN 4 in international networks) with a total length of $966 \mathrm{~km}$, the section of which crosses the Altai Republic, goes to the border with Mongolia. The republican center of Kyzyl (Tyva) is connected with Mongolia by the federal highway "Yenisei" (R-257) with a total length of $1,063 \mathrm{~km}$, the section of which also approaches the border. A distinctive feature of the Russian-Mongolian border within both republics is the relief features that determine not only inaccessibility, but also the sparse population of the adjacent areas [10].

The population of Altai and Tyva Republics is slightly more than 530 thousand people, but in the regions bordering Mongolia, the number of residents is significantly reduced, and the population density index does not exceed 1.8 people $/ \mathrm{km} 2$. This is due to the difficult climatic conditions of the highlands, weak development of various infrastructures - energy, social, economic. The population of the border areas is employed in agricultural production, in which crop farming - the cultivation of grain crops - plays an important role along with transhumance and stabling livestock breeding [9].

In the aimaks of neighboring Mongolia - Bayan-Ulgiy, Uvs, Zavkhan - no more than 450 thousand people. The population is also employed in agriculture with a predominant proportion of sheep breeding, goat breeding, and horse breeding. The livestock breeding of 
these aimaks of Mongolia creates the main produce - cattle and small ruminants in live form, as well as wool, meat, and milk, with a low proportion and small variety of crop production [11-13].

In this regard, it can be assumed that complementarity of needs in both agricultural and other products - coal, food products, building materials, sawn timber, and other goods - will facilitate the involvement of the population of the border areas of both countries in exchange relations, entrepreneurship, small and medium businesses.

To form and develop trade and economic relations, it is necessary to expand the transport infrastructure, create transport routes and checkpoints in these border areas, which constitute almost half of the Russian-Mongolian section of the border.

The plans for the railway construction of the Russian Federation envisage the extension of the Barnaul-Biysk line to Gorno-Altaisk and the construction of the Kuragino-Kyzyl branch on Russian territory in the near future, while the main and only points on the Russian-Mongolian border are automobile checkpoints of Tashanta-Tsagaannuur (aimak Bayan-Ulgiy ), Khandagayty-Borshoe, and Erzin (aimak Uvs), which are also in need of development, creation of modern customs warehouses and terminals [14].

Transport and economic relations for the border areas of Russia and Mongolia within the borders of the Republic of Buryatia are currently possible for five of the two dozen administrative regions located on the Trans-Siberian Railway. Another nine regions of the republic, along which the sections of the federal highways "Baikal" R-258 (AN-6), "Amur" R-297 (AN-30) pass, as well as connecting roads A-333 (from Kultuk through Mondy to the border with Mongolia, the Khankh point) and A-340 (from Ulan-Ude through Kyakhta to the border with Mongolia, the Aganbulag point), have access to the border aimaks of Mongolia by motor roads.

The location of Buryatia confined to the mountainous areas of Southern Siberia and largely determined the wealth and diversity of the Republic's mineral resources - ores of non-ferrous and ferrous metals and non-metallic industrial raw materials. These deposits began to be actively developed, and practically all extracted ore was enriched from the last century. Territorial remoteness from consumers, transportation costs, and limited local sales markets have generated a peripheral economy in Buryatia, which, in the market conditions and in dependence on world prices for mining and valuable raw materials, with weak infrastructural provision of industrial sites, has been characterized by crisis phenomena throughout the last 20 years [9].

The changing role of Siberia in geopolitics and the ability to develop a number of industries, both extracting and processing (aircraft engineering, bridge metal structures, cellulose, electrical equipment, canned meat, etc.), if not eliminate the dependence of regional economy on the environment, then, at least, it creates conditions for the development of export-import relations with its nearest neighbors.

Aimaks of Mongolia - Hovsgel, Bulgan, Selenge - have significant reserves of fuel and energy resources, in particular, coals, which are actively operated, and power generating coal is supplied to local consumers. Other types of resources, besides a variety of crude ore, are phosphorites, rock salt, biotite, uranium, gemstones [15]. Not only minerals, but also industrial and agrarian products of these regions of Mongolia need to be exported. Imports for the country are industrial equipment, petroleum products, machinery, and other consumer goods [16]. The Mongolian market is not crowded, and the existing opportunities of the Trans-Mongolian Railway (Ulan-Ude - Sukhe-Bator - Ulan-Bator, further to ZamynUude) are clearly not enough to develop transport and economic relations with Russia and other countries of the Eurasian Economic Union [EAEU] [17, 18].

The Transbaikal Territory has a fairly long border with Mongolia (about $800 \mathrm{~km}$ ), but a direct railway crossing equipped and actively maintained is located in the south-eastern part of the region, where Solovievsk station is connected to the Chuluunhoroot point of the 
Erentsav - Choibalsan railway. The Transbaikal Territory is generally rich in mineral resources, but it is the eastern Transbaikali region that is rich in rare and special ores of non-ferrous metals, excessive for the region timber reserves, significant hydropower potential, and valuable for Transbaikalia chernozem and kastanozem soils. This territorial combination of natural resources allowed developing mining and metallurgical production, to produce electricity at the GRES (state-owned district power plant - SDPP) using local brown and hard coal. In the south-east, the main sowing areas of the region are concentrated, beef cattle breeding and sheep breeding are developed.

Mountain relief, seismicity, climatic conditions, permafrost, and inversion temperature stratification of air have determined difficult conditions for life. At the same time, the location of the Transbaikal Territory at the railway "entrance" to the Far East determined the transit role of this region in the promotion of goods from European Russia and other regions of Siberia to the Russian Far East and the countries of the Asia-Pacific region to establish mutually beneficial cooperation with them. But the favorable situation of the Transbaikal Territory, borderline for Mongolia and China at the same time, has yet to be fully realized.

Aimaks of Mongolia - Hantiye and Dornod - are also located in a zone of extremely continental climate, when the winter period is cold and with little snow, and the summer is warm and short with large daily temperature fluctuations. Mountain and geological features of the formation of the region determined the presence in grounds of these territories of coals, various ores, raw materials for building materials - partly potential, partly developed and used in the domestic market. The dry steppes of the eastern plains of aimak Dornod and the mountain forests of aimak Khanty preserve their biodiversity, which allows the sites of these areas to be considered as natural reserves and create conditions for the tourist attractiveness of the region. Aimak Uvs, on whose territory the Ubsunur Biosphere Reserve is located, has similar advantages for long-term development $[19,20]$.

\section{Conclusion}

Therefore, at the present time, the existing transport flow between the boundary aimaks of Mongolia and the eastern regions of Russia basically has a rather diverse structure, the elements of which are mineral raw materials, oil products, industrial equipment, and consumer goods $[21,22]$. Modernization and development of the border railway transport network will create opportunities for mass transportation of not only coal, grain, wool, and other goods, but also for the transportation of passengers, and, consequently, for the expansion of international trade and economic relations between the border regions of the two countries as a part of transport projects "Steppe Route" (track gauge $1520 \mathrm{~mm}$ ) and "Silk Road" (track gauge $1435 \mathrm{~mm}$ ), in the implementation of which the business structures of Mongolia, Russia, Kazakhstan, and China are interested [23, 24].

\section{References}

1. M.R. Sigalov, V.A. Lamin, Railway construction in the practice of economic development of Siberia (Nauka, Novosibirsk, 1988)

2. V.A. Lamin, V.Yu. Plenkin, V.Ya. Tkachenko, Global track: the development of the transport system in the east of the country (UrB RAS, Ekaterinburg, 1999)

3. Yu.N. Kruchkin, Mongolia. Geographical encyclopedia (Ulan Bator, 2009)

4. Atlas Railways (FSUE “Omsk Cartographic Factory”, 2012) 
5. A.Ya. Yakobson, D. Balzhinnyam, Collective monograph. Irkutsk: IrSURE 2, 213-216 (2004)

6. D. Molomzhamts, Foreign economic relations of Mongolia with Russia and prospects for their development, http: www.unix.transecon.ru/imepi/Doclads

7. B. Erdenebat, On improving the effectiveness of Mongolian-Russian cooperation, http: www.unix.transecon.ru/imepi/Doclads

8. E. Koch, Report of Small and Medium Size Business in Mongolia (TACIS SMENON Report, UB, 1997)

9. Russian Statistical Yearbook 2017 (Stat.coll./Rosstat., M., 2017)

10. Atlas "Motor Roads” (FSUE “Omsk Cartographic Factory”, 2012)

11. The World Factbook-East\&Southeast Asia, www.librarY/publications/the-worldfactbook

12. Russia and countries of the world 2016 (Stat.coll./Rosstat., M., 2016)

13. Ministry of Food and Agriculture of Mongolia, www.mofa.gov.mn

14. Transport strategy of the Russian Federation for the period up to 2030, the order of the Government of the Russian Federation of 22 November. 2008 №1734-r

15. Ministry of Mining of Mongolia, www.mn.gov.mn

16. National Statistical Committee of Mongolia, www.nso.mn

17. Ministry of roads and transport of Mongolia, www.mort.gov.mn

18. M. Lagutina, Eurasian Economic Union Foundation: Issues of Global Regionalization (Eurasian Border Review, 2014)

19. Modern Mongolia: an encyclopedic reference book (Ulan Bator, 2011)

20. National atlas of the Mongolian People's Republic (problems and scientific content) (Nauka. Siberian Branch, Novosibirsk, 1989)

21. D. Balzhiniyam, A.Ya. Yacobson, The economic and geographical potential of the Mongolian-Russian interrelations (Publishing House of the V.B. Sochava Institute of Geography SB RAS, Irkutsk, 2009)

22. Website of Administrative Office Of Altanbulag Free Trade Zone, http://www.altanbulag.mn

23. T. Batbayar, Renovation of Mongolia of the 21-th century and future development patterns (Mongolian development research centre, Ulaanbaatar, 2010)

24. N.K. Isingarin, Logistics of international rail transport (Econometroconsulting, Almaty, 2006) 